\title{
Discovery of Novel, Potent and Long Acting CCK Analogs
}

\author{
Robert Hunter ${ }^{1}$, Andrew Carpenter ${ }^{1}$, Erin Swiger ${ }^{1}$, Makda Mebrahtu', \\ Robert Wiard', Andrea Acker ${ }^{1}$, Shane Roller ${ }^{1,2}$, Mark Paulik ${ }^{1,2}$, \\ and Ved Srivastava*,1,2 \\ ${ }^{1}$ GlaxoSmithKline, 5 Moore Dr. Research Triangle Park, NC, 27709, USA; \\ ${ }^{2}$ Phoundry Pharmaceuticals Inc., 6 Davis Dr., Research Triangle Park, NC, 27709, USA
}

\section{Introduction}

Cholecystokinin (CCK) is a sulfated neuropeptide hormone and neurotransmitter synthesized by cells in the mucosal epithelium of the small intestine and secreted in the duodenum. The $C$-terminal fragment CCK-8, inhibits gastric emptying as well as other physiological processes involved in satiety.

\section{Results and Discussion}

While the physiological effects of inhibiting gastric emptying, decreasing gastric acid secretion and satiety make CCK- 8 an interesting peptide for the treatment of obesity, the anxiolytic effect which is normally attributed to the Cholecystokinin B receptor, complicate its use. In our research, we sought to synthesize a long acting peptide CCK agonist which was selective for the CCK-A receptor, had desired potency and sufficient solubility to be dosed using an implanted osmotic mini pump. To do this, we used much of the data which has been previously reported and attempted to systematically assemble it into a single peptide agonist with the desired pharmacokinetic profile.

- Potency in vitro (>9.5 $\left.\mathrm{pIC}_{50}\right)$

- 200 fold selectivity over CCK-B

- $45 \mathrm{~min}$ or better $\mathrm{t}_{1 / 2}(\mathrm{CCK}-8=20 \mathrm{~min})$

- Equal or better food intake reduction than CCK-8

- Solubility $>160 \mathrm{mg} / \mathrm{mL}$

A screening of the literature provided the following information:

- Sulfation of Tyr27 is required for biological activity of the native peptide at the CCK-A receptor [1]

- Non hydrolyzable Sulfated Tyr27 mimetics are desired for synthetic ease, chemical stability [1]

- Activity is restored to non-sulfated CCK-4 when Met31 is replaced with a Lys(Tac) residue [2]

- Hexapeptide analogs retain potency when both Met28 and Met31 are replaced with norleucine [3]

- N-methyl-Phenylalanine enhances metabolic stability [4]

- N-terminal pGlu-Gln enhances metabolic stability [5]

The literature modifications were systematically incorporated, resulting in peptide 34 (Table 1) which had the desired potency, selectivity, food intake reduction and a solubility $>150 \mathrm{mg} / \mathrm{mL}$. While endogenous CCK-8 lacks the selectivity duration of action and solubility to be used as an effective tool compound in combination studies, the introduction of modifications to the peptide sequence gleaned from the literature enabled us to generate a suitable molecule.

Table 1. Key analogs.

\begin{tabular}{|c|c|c|c|c|c|c|c|}
\hline \multirow{2}{*}{$I D$} & \multirow{2}{*}{ SEQUENCE } & \multicolumn{3}{|c|}{ CCK CCK Selec. } & \multicolumn{3}{|c|}{$\begin{array}{l}\text { A.F.I. A.F.I. A.F.I. } \\
(D I O)(D I O)(D I O)\end{array}$} \\
\hline & & $A$ & $B$ & $A / B$ & $6 h r$ & $15 \mathrm{hr}$ & $30 \mathrm{hr}$ \\
\hline 1 & $\mathrm{D}\left(\mathrm{Y}-\mathrm{SO}_{3} \mathrm{H}\right) \mathrm{MGWMDF}-\mathrm{NH}_{2}(\mathrm{CCK}-8)$ & 10.5 & 9.8 & 5 & -59 & -26 & -10 \\
\hline 33 & (pGlu)KKKRD(F-CH $\left.\mathrm{SO}_{3} \mathrm{H}\right) \mathrm{LGW}(\mathrm{K}-\mathrm{Tac}) \mathrm{D}(\mathrm{mePhe})-\mathrm{NH}_{2}$ & 9.8 & 7.5 & 200 & -91 & -69 & -48 \\
\hline 34 & (pGlu)KKKKKRD(F-CH $\left.{ }_{2} \mathrm{SO}_{3} \mathrm{H}\right) \mathrm{LGW}(\mathrm{K}-\mathrm{Tac}) \mathrm{D}(\mathrm{mePhe})-\mathrm{NH}_{2}$ & 9.9 & 7.5 & 251 & -100 & -90 & -68 \\
\hline 35 & $\begin{array}{c}\left.\text { (pGlu)KKKKKKKKRD(F-CH } \mathrm{SO}_{3} \mathrm{H}\right) \mathrm{LGW}- \\
\text { (K-Tac)D(mePhe)-NH} \mathrm{NH}_{2}\end{array}$ & 9.6 & 7 & 398 & -100 & -95 & -73 \\
\hline
\end{tabular}


The novel peptide 34 (Figure 1) demonstrated a $\mathrm{pEC}_{50}$ of 9.9 and a duration of action greater than $60 \mathrm{~h}$ in an acute DIO mouse model. The improvements to CCK-8 translate to an $\mathrm{ED}_{50} 0.09 \mathrm{mg} / \mathrm{kg} / \mathrm{day}$ and an observed weight loss of $23 \%$ when dosed in combination with Exendin-4 in the 14 day DIO rat model (Figure 2).

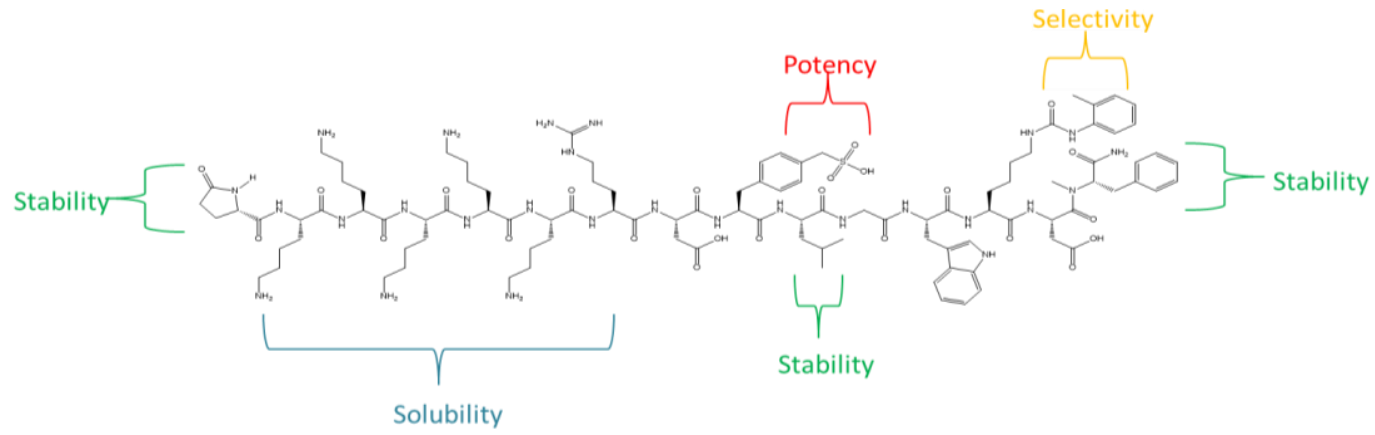

Fig. 1. Peptide 34.

\section{\% Change in Body Weight from Baseline (Adjusted to Vehicle Control)}

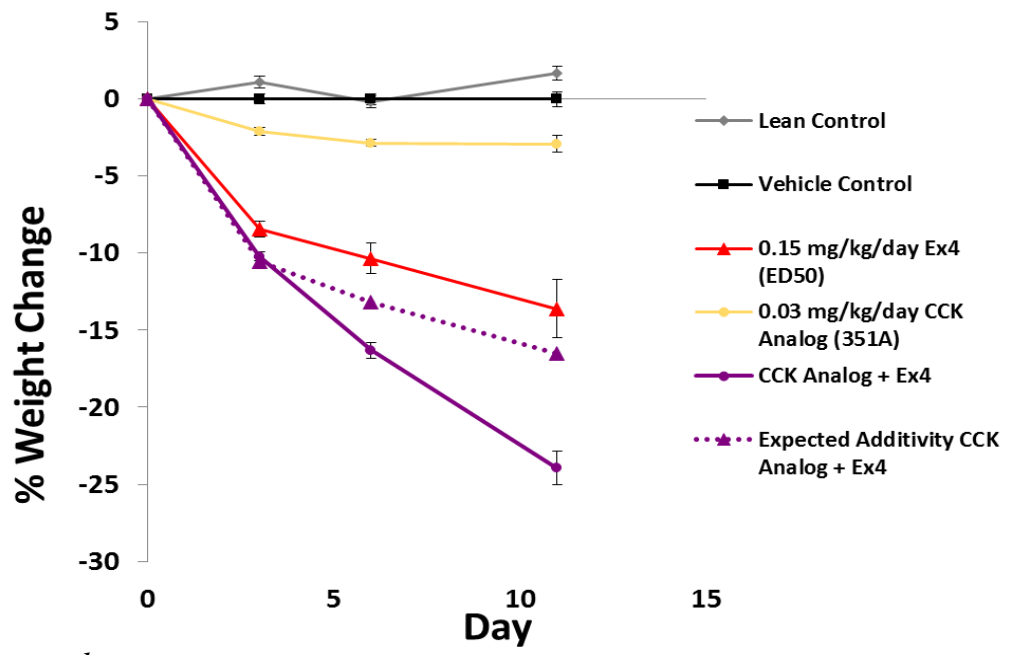

Fig. 2. In vivo results.

\section{References}

1. Marseigne, I., Roy, P., Dor, A., Durieux, C., Pelaprat, D., Reibaud, M., Blanchard, J.C., Roques, B.P. J. Med. Chem. 32, 445-449 (1989), http://dx.doi.org/10.1021/jm00122a026

2. Sugg, E.E., Kimery, M.J., Jian, Mei Ding, Kenakin, D.C., Miller, L.J., Queen, K.L., Rimele, T.J. J. Med. Chem. 38, 207-211 (1995), http://dx.doi.org/10.1021/jm00001a027

3. Pierson, M.E., Comstock, J.M., Simmons, R.D., Kaiser, F., Julien, R., Zongrone, J., Rosamond, J.D. J. Med. Chem. 40, 4302-4307 (1997), http://dx.doi.org/10.1021/jm970477u

4. Simmons, R.D., Blosser, J.C., Rosamond, J.R. Pharmacology Biochemistry and Behavior 47, 701-708 (1994), http://dx.doi.org/10.1016/0091-3057(94)90176-7

5. Irwin, N., Frizelle, P., Montgomery, I.A., Moffett, R.C., O'Harte, F.P.M., Flatt, P.R. Diabetologia 55, $2747-$ 2758 (2012), http://dx.doi.org/10.1007/s00125-012-2654-6 